\title{
Children Television Viewing and Antisocial Behavior: Does the Duration of Exposure Matter?
}

\author{
Mohammad Reza Nazari \\ Department of Communication, Faculty of Modern Languages and Communication, \\ University Putra Malaysia, 43400, Selangor, Malaysia \\ E-mail: nazari860@yahoo.com \\ Md Salleh Bin Hj Hassan (Corresponding Author) \\ Department of Communication, Faculty of Modern Languages and Communication, \\ University Putra Malaysia, 43400, Selangor, Malaysia \\ Tel: +60- 389468784 E-mail: salleh@ fbmk.upm.edu.my \\ Mohd Nizam Osman \\ Department of Communication, Faculty of Modern Languages and Communication, \\ University Putra Malaysia, 43400, Selangor, Malaysia \\ E-mail: nizamosman@fbmk.upm.edu.my \\ Saadat Parhizkar \\ Social Determinants of Health Research Center, Yasuj University of Medical Sciences \\ (YUMS), Yasuj, Iran \\ E-mail: parhizkarsa@gmail.com \\ Megat Al-Imran Bin Yasin \\ Department of Communication, Faculty of Modern Languages and Communication, \\ University Putra Malaysia, 43400, Selangor, Malaysia \\ E-mail: megat@putra.upm.edu.my
}

Accepted: Feb 03, 2013 Published: March 03, 2013

Doi:10.5296/jsr.v4i1.3115 URL: http://dx.doi.org/10.5296/jsr.v4i1.3115

\begin{abstract}
Media violence is related to media presentation of aggressive and violent behaviour directed at characters in the media story. Specifically, researchers have identified evidence that children's exposure to television violence is directly related to immediate and later aggressive behaviour. The relationship between television exposure and students; aggression behavior has not been studied extensively in Iranian elementary students. The purpose of this study was to assess the relative effects of television exposure on aggression behaviour among elementary students in Iran.A cross-sectional survey was conducted on 424 primary school students
\end{abstract}


(aged 7-12 years) in the five provinces of Iran which selected trough a multi-stage random sampling from different geographical areas comprising of North, South, West, East and central area of Iran. This survey investigated whether exposure to television program was related to children's use of social aggression that explored using Buss- Perry standard questionnaire. The results of the study revealed a significant relationship between amount of exposure to television program and aggressive behaviours among primary school students $(\mathrm{p}<0.05)$. In addition, students' aggression was positively associated with watching movies with action genre $(\mathrm{p}<0.05)$. Furthermore students' leisure time filling with television was moderately correlated with their aggression level. The findings suggest that young people's aggressive behaviours may be related to their frequent exposure to television programs and its violent contents. Results of this study suggested the need for further attention on television children's program production to protect them from antisocial behaviours and interventions for violence-exposed children in order to reduce negative outcomes.

Keywords: Aggression, Exposure, Students, Television

\section{Introduction}

Media violence has been a public concern ever since the 1920s when researchers sought to understand the effects of motion pictures on children (Blumer, 1933; Anderson, 2008; Bratic, 2008; Anderson \& Hanson, 2009). With the growth of the television in the 1950s, interest in the effects of media violence increased (Vande berg, Wenner, \& Gronbeck, 2004; José Martínez, Prieto, \& Farfán, 2006). Especially television, given its preeminent role in mass communication during the second half of the 20th century, has been at the centre of attention from both popular media and researchers. In particular, studies have found evidence that children's exposure to television violence is positively related to immediate and later aggressive behaviour (Huesmann et al., 2003). There is worldwide public health concern at increases in aggressive behaviours and acts of violence by children and young people (World Health Organization, 2002). Health professionals sometimes give advice, including psycho-education about contributory environmental factors, on managing aggression in children and young people. Professional organizations, such as the American Academy of Paediatrics (1984), have drawn attention to possible links between viewing violence within entertainment media, such as television and such behaviour (Mitrofan et al., 2009). There is no doubt that television has an impact on all of us, especially on children (Grimes et al., 2008). Childhood aggression can be a serious problem particularly among children who exhibit aggression across time and contexts (Bendersky et al., 2006) as they are more likely to exhibit future juvenile delinquency (Hinton et al., 2003) and violent offending (Broidy et al., 2003; bendersky et al.,2006). It is known that even brief exposure to violent movies scenes causes significant increases in aggression in both children and adults (Bushman and Huesmann, 2001). When children are repeatedly exposed to media violence they have an increased likelihood of becoming aggressive adolescents (Bushman and Huesmann, 2001). As such, exposure to media violence is a significant risk factor for youth. Long-term effects involve a learning process. Each violent media episode is essentially one more learning trial. Researchers have established that there is an increase of aggressive behavior after being 
exposed to television or movie violence (Bandura et al., 1963; Funk et al., 2004; Savage and Yancey, 2008a; Anderson et al., 2010). Children who watch more television and play violent video games are more likely to view violence and exhibit hostile attributional biases (Buchanan et al., 2002). Additional finding showed that physically aggressive children were more likely than non-physically aggressive children to watch violent movies (Buchanan et al., 2001; Savage, 2008b). Television plays an increasingly powerful role in young children's everyday life due to increased TV exposure, more TV sets in households, more channels available, increased broadcasting time and transmission of increasingly international TV programmes for children (Yoshimi, 2003; Lahikainen, et al., 2004;Korhonen and Lahikainen, 2007; Jones et al., 2010). The everyday role of TV for children is increasingly significant and relevant due to the greater burden of parents' work and hence their diminished opportunities for interaction with their children (Taimalu, 2006; Lahikainen et al., 2007). Children spend more time with television and discuss less with their parents than before (Evans et al., 2011).

Of all the mass media, television violence has the greatest potential for both short-term and long-term effects upon children. In light of all the situations where children are affected negatively by viewing violence, there is a need for a study of the effects of television violence on children. The purpose of this study is to examine people's self-reported exposure and perception to television violence and their perceived behavior. On the other word the study tended to examine the relationship between violent behavior in primary school students' and their exposure to television programs.

\section{Methodology}

A cross-sectional study was carried out among primary school students between September and December, 2011. A multi-stage random sampling was used to select the schools. First, five provinces out of the 31 provinces in Iran from different geographical areas of country including North (Gilan Province), South (Hormozgan province), West (Kurdistan Province), East (Yazd Province) and Central region (Markazi Province) were selected randomly. Secondly, one city and one village were selected from each of these five provinces by simple random sampling. Since, based on country's rule, there are separate schools for boys and girls, so in order to explore relationship between TV viewing habits and aggression behaviours in children, from each selected areas (rural and urban area of each selected province) two schools were selected randomly covering both genders, adding up to a total of 20 schools. The subjects of current study consisted of 424 students from grade one to five (7-12 years old) from both genders. All students were granted parental permission and signed their own assent forms before participating. The survey was administered in a quiet place at the students' home. Children were interviewed by researcher with reading question stems and answer choices, and allowed students to answer the questions. Upon completion, children received a novelty pencil in thanks for their participation.

\subsection{Participants}

Four hundred twenty four primary students from different grades (grade one to five) were 
recruited for the present study. The participants were residing in five provinces of Iran in different geographical areas. Extremely half of the students were male (50.5\%) and residing in urban area. The mean age of children were $9.76 \pm 1.61$ years ranging from 7 to 12 years. The students' family size and birth rank were $4.36 \pm 1.34$ and $1.82 \pm 1.26$ respectively. The students' fathers and mothers mean age were $38.82 \pm 5.91$ and $34.28 \pm 5.54$ years. The majority of students' father worked as nonprofessional employers $(52.1 \%)$ and occupation of most their mothers were housewife $(87.5 \%)$. Almost of the students' parents had finished primary school as their education level $(26.7 \%$ and $36.8 \%$ for fathers and mothers respectively).

\subsection{Instrument}

A validated and reliable self-administered, structured questionnaire was used for data collection. Content validity of the questionnaire was ascertained by an expert panel, which comprised three mass communication specialists, an epidemiologist, an educational psychologist and a clinical psychologist with specialty in children behaviours.

Reliability (internal consistency) was assessed by using Cronbach's alpha. The Cronbach's alpha coefficient was 0.94 for the 25 aggression questions indicated adequate reliability of the questionnaire (Nunally, 1978). The questionnaire was pretested among 30 elementary students for checking the clarity of the items excluded from the study samples. The questionnaire consisted of three sections including socio-demographic information, media using habits and Buss Perry Scale for assessing aggression level.

\subsection{Buss-Perry's Aggression Questionnaire (AQ)}

Buss- perry's aggression Questionnaire was validated and made norm base on Iranian culture previously (Mohammadi, 2007; Samani, 2008) and consequently 4 items deleted from original questionnaire and finally a 25 items questionnaire was prepared. Trait aggression was measured by the total score of the AQ and scores of the subscales including Physical Aggression (items 1 to 7), Verbal Aggression (items 8 to 12), Anger (items 13 to 17), and Hostility (items 18 to 25). The AQ comprises 25 items in a 5-point Likert format from 0 (extremely uncharacteristic of me) to 4 (extremely characteristic of me). Aggression level of students defined as Low-aggressive (percentile $<25 \%$ of aggression score); Moderate aggression percentile $25-75$ and High aggression percentile $>75 \%$. The required time for completion of each questionnaire was equal to 30 minutes.

\subsection{Data Analysis}

Bivariate correlation analysis, one- way ANOVA followed by Post Hoc test (Duncan) and linear regression analysis were performed in the data analysis, using SPSS version 18 . The level of significance for all statistics was set at $p<0.05$. 


\section{Results}

Regarding access to mass media, $100 \%$ of the population had television, followed by hand phone $(85.84 \%)$, fixed phone (78.3\%), and CD and DVD player (60.61\%). The least accessible medium in participants' home was internet (14.4\%), but the finding showed that these orders were not similar in all provinces, for instance sixth place was belonged to internet in Kurdistan (Table 1).

Table 1. Distribution of respondents' access to Media at home by province

\begin{tabular}{|c|c|c|c|c|c|c|}
\hline \multirow[t]{2}{*}{ Mass Media } & \multicolumn{5}{|l|}{ Provinces } & \multirow{2}{*}{$\begin{array}{l}\text { Total } \\
\text { N }(\%)\end{array}$} \\
\hline & $\begin{array}{l}\text { Gilan } \\
\text { N (\%) } \\
\end{array}$ & $\begin{array}{l}\text { Markazi } \\
\mathbf{N}(\%)\end{array}$ & $\begin{array}{l}\text { Yazd } \\
\mathbf{N}(\%) \\
\end{array}$ & $\begin{array}{l}\text { Hormozgan } \\
\mathbf{N}(\%)\end{array}$ & $\begin{array}{l}\text { Kurdistan } \\
\mathbf{N}(\%) \\
\end{array}$ & \\
\hline TV & $114(100)$ & $68(100)$ & $56(100)$ & $110(100)$ & $76(100)$ & $424(100)$ \\
\hline Radio & $44(38.6)$ & $19(27.9)$ & $30(53.6)$ & $15(13.6)$ & $21(27.6)$ & $129(30.4)$ \\
\hline Fixed Phone & $105(92.9)$ & $55(80.9)$ & $49(87.5)$ & $57(51.8)$ & $66(86.8)$ & $332(78.30)$ \\
\hline Hand Phone & $98(86)$ & $63(92.6)$ & $51(91.1)$ & $91(82.7)$ & $61(80.3)$ & $364(85.84)$ \\
\hline Computer & $35(30.7)$ & $24(35.5)$ & $26(46.6)$ & $29(26.4)$ & $34(44.7)$ & $148(34.9)$ \\
\hline Internet & $11(9.6)$ & $10(14.7)$ & $9(16.1)$ & $6(5.5)$ & $25(32.9)$ & $61(14.4)$ \\
\hline $\begin{array}{l}\text { CD \& DVD } \\
\text { Player }\end{array}$ & $102(89.5)$ & $59(86.8)$ & $45(80.4)$ & $49(44.5)$ & $42(55.3)$ & $257(60.61)$ \\
\hline Video Game & $17(14.9)$ & $13(19.1)$ & $14(25)$ & $11(10)$ & $14(18.4)$ & $69(16.3)$ \\
\hline
\end{tabular}

The finding indicated that $40.6 \%$ of students watched TV for 3-4.99 hours/day, while only $3.1 \%$ of students were exposed to television less than one hour daily. The mean of watching TV duration was $4.28 \pm 1.89$ hour per day (Table 2).

Table 2. Distribution of respondents' watching TV duration by province

\begin{tabular}{|c|c|c|c|c|c|c|}
\hline \multirow[b]{2}{*}{ Time } & \multicolumn{5}{|l|}{ Provinces } & \multirow{2}{*}{$\begin{array}{l}\text { Total } \\
\mathrm{N}(\%)\end{array}$} \\
\hline & $\begin{array}{l}\text { Gilan } \\
\mathrm{N}(\%)\end{array}$ & $\begin{array}{l}\text { Markazi } \\
\mathrm{N}(\%)\end{array}$ & $\begin{array}{l}\text { Yazd } \\
\mathrm{N}(\%)\end{array}$ & $\begin{array}{l}\text { Hormozgan } \\
\mathrm{N}(\%)\end{array}$ & $\begin{array}{l}\text { Kurdistan } \\
\mathrm{N}(\%)\end{array}$ & \\
\hline $\begin{array}{l}\text { More than } \\
5 \text { hours }\end{array}$ & $11(9.6)$ & $23(33.8)$ & $10(17.9)$ & $30(27.3)$ & $16(21.1)$ & $90(21.2)$ \\
\hline 3 to 5 hours & $64(56.1)$ & $27(39.7)$ & $23(41.1)$ & $38(34.4)$ & $20(26.3)$ & $172(40.6)$ \\
\hline $\begin{array}{l}\text { One to } 3 \\
\text { hours }\end{array}$ & $38(33.3)$ & $17(25)$ & $22(39.3)$ & $40(36.4)$ & $32(42.1)$ & $149(35.1)$ \\
\hline $\begin{array}{l}\text { Less than } \\
\text { one hours }\end{array}$ & $1(0.9)$ & $1(1.5)$ & $1(1.8)$ & $2(1.8)$ & $8(10.5)$ & $13(3.1)$ \\
\hline Mean \pm SD & $4.07 \pm 1.21$ & $4.97 \pm 2.18$ & $4.16 \pm 1.68$ & $4.45 \pm 1.99$ & $3.82 \pm 2.26$ & $4.28 \pm 1.89$ \\
\hline
\end{tabular}

A linear regression analysis was conducted to evaluate the relative impact of time spent watching television by students on their aggression level. It was plotted line graphs with the 
$\mathrm{x}$-axis representing the media exposure by hour per day and the $\mathrm{y}$-axis representing the aggression level of respondents. Results indicated that there is a significant relationship between time of TV exposure and tendency of students to aggressive behaviour $(p<0.001)$ that display in Figure 1.

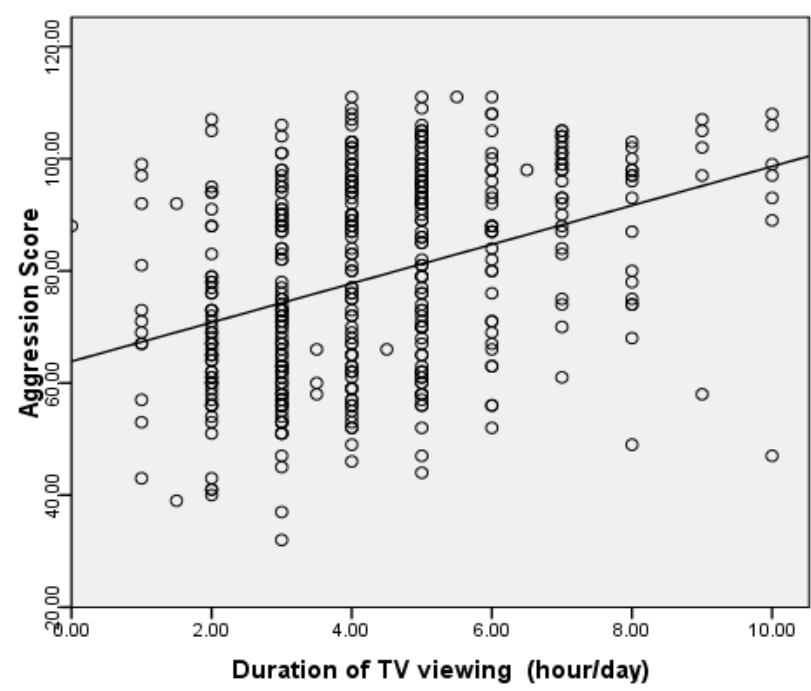

Figure 1. Relationship between duration of TV viewing and students' aggression level.

In order to further exploring this phenomenon and considering distribution of data, a Spearman rank correlation was conducted to test the relationship between the amount of leisure time fill with television program and students' aggression level. Students' leisure time filling with television was moderately correlated with their aggression level ( $r s=0.438$, $\mathrm{p}<0$.001). Different components of aggression also revealed significant correlation $(\mathrm{p}<0.05)$ with duration of TV viewing by students ( $r s=0.38,0.377,0.379$ and 0.378 for physical, verbal, anger and hostility respectively (Table 3 ).

Table 3. Correlation of leisure time filling with TV watching and aggression level among students

\begin{tabular}{|c|c|c|c|c|c|c|c|c|}
\hline & & & $\begin{array}{l}\text { Total } \\
\text { Aggressi } \\
\text { on }\end{array}$ & $\begin{array}{l}\text { Physica } \\
1\end{array}$ & $\begin{array}{l}\text { Verba } \\
1\end{array}$ & Anger & $\begin{array}{l}\text { Hostilit } \\
\mathrm{y}\end{array}$ & $\begin{array}{l}\text { TV } \\
\text { viewing } \\
\text { Time }\end{array}$ \\
\hline \multirow[t]{4}{*}{$\begin{array}{l}\text { Spearma } \\
\text { n's rho }\end{array}$} & \multirow[t]{3}{*}{$\begin{array}{l}\text { Total } \\
\text { Aggressio } \\
\mathrm{n}\end{array}$} & $\begin{array}{l}\text { Correlati } \\
\text { on } \\
\text { Coefficie } \\
\text { nt }\end{array}$ & 1.000 & $.876^{* *}$ & $\begin{array}{l}.830^{*} \\
*\end{array}$ & $\begin{array}{l}.838^{*} \\
*\end{array}$ & $.905 * *$ & $.438 * *$ \\
\hline & & Sig. & & .000 & .000 & .000 & .000 & .000 \\
\hline & & $\mathrm{N}$ & 424 & 424 & 424 & 424 & 424 & 424 \\
\hline & $\begin{array}{l}\text { Physical } \\
\text { Aggressio }\end{array}$ & $\begin{array}{l}\text { Correlati } \\
\text { on }\end{array}$ & $.876^{* *}$ & 1.000 & $\begin{array}{l}.645 * \\
*\end{array}$ & $\begin{array}{l}.694 * \\
*\end{array}$ & $.682 * *$ & $.380 * *$ \\
\hline
\end{tabular}




\begin{tabular}{|c|c|c|c|c|c|c|c|}
\hline \multirow[t]{3}{*}{$\mathrm{n}$} & $\begin{array}{l}\text { Coefficie } \\
\text { nt }\end{array}$ & & & & & & \\
\hline & Sig. & .000 & & .000 & .000 & .000 & .000 \\
\hline & $\mathrm{N}$ & 424 & 424 & 424 & 424 & 424 & 424 \\
\hline \multirow[t]{3}{*}{$\begin{array}{l}\text { Verbal } \\
\text { Aggressio } \\
n\end{array}$} & $\begin{array}{l}\text { Correlati } \\
\text { on } \\
\text { Coefficie } \\
\text { nt }\end{array}$ & $.830 * *$ & $.645^{* *}$ & 1.000 & .586 & $.720 * *$ & $.377 * *$ \\
\hline & Sig. & .000 & .000 & & .000 & .000 & .000 \\
\hline & $\mathrm{N}$ & 424 & 424 & 424 & 424 & 424 & 424 \\
\hline \multirow[t]{3}{*}{ Anger } & $\begin{array}{l}\text { Correlati } \\
\text { on } \\
\text { Coefficie } \\
\text { nt }\end{array}$ & $.838 * *$ & $.694 * *$ & $\begin{array}{l}.586^{*} \\
*\end{array}$ & 1.000 & $.698 * *$ & $.379 * *$ \\
\hline & Sig. & .000 & .000 & .000 & & .000 & .000 \\
\hline & $\mathrm{N}$ & 424 & 424 & 424 & 424 & 424 & 424 \\
\hline \multirow[t]{3}{*}{ Hostility } & $\begin{array}{l}\text { Correlati } \\
\text { on } \\
\text { Coefficie } \\
\text { nt }\end{array}$ & $.905 * *$ & $.682 * *$ & $\begin{array}{l}.720 * \\
*\end{array}$ & $\begin{array}{l}.698^{*} \\
*\end{array}$ & 1.000 & $.378 * *$ \\
\hline & Sig. & .000 & .000 & .000 & .000 & & .000 \\
\hline & $\mathrm{N}$ & 424 & 424 & 424 & 424 & 424 & 424 \\
\hline \multirow[t]{3}{*}{$\begin{array}{l}\text { TV } \\
\text { viewing } \\
\text { Time }\end{array}$} & $\begin{array}{l}\text { Correlati } \\
\text { on } \\
\text { Coefficie } \\
\text { nt }\end{array}$ & $.438 * *$ & $.380 * *$ & $\begin{array}{l}.377 * \\
*\end{array}$ & $\begin{array}{l}.379 * \\
*\end{array}$ & $.378 * *$ & 1.000 \\
\hline & Sig. & .000 & .000 & .000 & .000 & .000 & \\
\hline & $\mathrm{N}$ & 424 & 424 & 424 & 424 & 424 & 424 \\
\hline
\end{tabular}

**. Correlation is significant at the 0.01 level (2-tailed).

Spearman correlation also was performed to explore the relationship of students' aggression level and spending leisure time with TV in different provinces and results showed that all provinces showed a direct and moderate correlation between aggression and duration of TV viewing ( $r s=0.3, p<0.05-r=0.57, p<0.001-r s=0.58, p<0.001$ and $r=0.298, p<0.01$ for Markazi, Yazd, Hormozgan and Kurdistan respectively) except Gilan province (rs=.092, $\mathrm{p}>0.05)$.

The results showed that mean of viewing television by aggressive students was $5.4 \pm 1.9$ hours, while low aggressive students spent $3.6 \pm 1.5$ hours to watch TV. In order to test whether the amount of exposure to TV programs and filling leisure time with watching television could affect the aggression level, an ANOVA test was conducted that showed a significant difference between duration of spending time for viewing television among various aggression level $(\mathrm{F}=32.11, \mathrm{p}<0.001)$ (Table 4$)$. This finding also was confirmed by 
Duncan post hoc test.

Table 4. Comparisons the mean of watching television duration by students' aggression level

4.

\begin{tabular}{|c|c|c|c|c|c|}
\hline \multirow[t]{2}{*}{ Aggression level } & \multirow[t]{2}{*}{$\mathrm{N}$} & \multicolumn{2}{|c|}{ TV viewing Duration } & \multirow[t]{2}{*}{$\mathrm{F}$} & \multirow[t]{2}{*}{ Sig. } \\
\hline & & Mean & SD & & \\
\hline Low (Percentile <25\%) & 107 & 3.60 & 1.55 & \multirow[t]{4}{*}{32.114} & \multirow[t]{4}{*}{.000} \\
\hline $\begin{array}{ll}\text { Moderate } & \text { (Percentile } \\
25-75 \%) & \end{array}$ & 217 & 4.08 & 1.76 & & \\
\hline High $($ Percentile $>75 \%)$ & 98 & 5.49 & 1.98 & & \\
\hline Total & 424 & 4.28 & 1.89 & & \\
\hline
\end{tabular}

\section{Discussion}

The finding indicated that almost of participants watched TV for 3-4.99 hours/day which was consistent with other researchers (Ghermez Cheshmeh et al., 2006; Razavi, et al., 2007; Mesri, 2011). Vittrup (2009) reported that the children watched about 3.5 hours of television on the preceding day. We found that exposure to more television programs are associated to antisocial behaviors at ages 7 to 12 years. The study showed a significant association between the amounts of time spent watching television and aggression level among participants. These results support study hypothesis in which we hypothesized that the amounts of time spent watching television would be positively associated with students' aggression level. Our findings confirmed and extended findings of others that time of exposure to television programs can promote aggression in real life. Research has indicated that viewing television violence is associated with aggressive behavior (Comstock and Paik, 1991; Christakis and Zimmerman, 2007). These results are consistent with theories suggesting that frequent television viewers are more likely to act and react in verbally aggressive ways rather than being physically violent (Gerbner and Gross, 1976; Shanahan and Morgan, 1999; Anderson and Dill, 2000). On the other hand some scholars believed that reducing exposure to violent media will reduce aggression behaviour among viewers specially children (Anderson et al., 2003).

The current study also showed the impact of time spent watching television by students on their tendency to aggressive behaviours which is in agreement with other researchers who reported similar finding in their studies (Barr-Anderson et al., 2011; Johnson et al., 2002)

These results are important because aggressive behaviour in the early childhood years has been repeatedly linked to violence in later youth and adolescence. (Tremblay, 2008; Barker et al., 2008). This later youth violence does not materialize suddenly from nowhere but rather develops as a continuum with escalating aggression (Christakis and Zimmerman, 2007).

\section{Conclusions}


The study found a strong, independent relationship between measures of exposure to media particularly television and aggression behaviour of students. The findings in this study added support to the recommendation that parents of young children limit not only the amount but also the content of their child's media exposure. Specifically, this study supported the recommendation that parents limit weekday television and video game time to $\leq 1$ hour and restrict access to adult media by limiting exposure to cable movie channels.

\section{References}

American Academy of Pediatrics.(1984). Task Force on Children, and Television. Children, adolescents and television. News and Comment. December 1984, 35(8).

Anderson ,C.A, Dill,K.E. (2000). Video games and aggressive thoughts, feelings, and behavior in the laboratory and in life. J Pers Soc Psychol,78 (4),772-90.

Anderson,D.R., \& Hanson,K.G.(2009).Children, Media, and Methodology. American Behavioral Scientist, 52(8), 1204-1219.

Anderson, C.A., Sakamoto, A., Gentile, D., Ihori, N., Shibuya, A., Yukawa, S., Naito, M., \& Kobayashi, K. (2008). "Longitudinal Effects of Video Games on Aggression in Japan and the United States." Pediatrics, 122 (5), 1067-1072.

Anderson,C.A., Berkowitz,L., Donnerstein,E., Huesmann,L.R., Johnson,J.D., Linz,D., Malamuth,N.M.,and Wartella,E.(2003). The Influence Of Media Violence On Youth. American Psychological Society, 4(3), 81-110.

Anderson,C.A., Shibuya,A., Ihori,N., Swing,E.L., Bushman,B.J., Sakamoto,A., Rothstein,H.R., Saleem,M.(2010). Violent Video Game Effects on Aggression, Empathy, and Prosocial Behavior in Eastern and Western Countries: A Meta-Analytic Review. Psychological Bulletin, 136(2), 151-173.

Bandura, A., Ross, D. and Ross, S. A. (1963). Imitation of film-mediated aggressive models. Journal of Abnormal and Social Psychology, 66(7), 3-11.

Barker,E.D., Boivin,M., Brendgen, M., Fontaine,N., Arseneault, L., Vitaro,F., Bissonnette, C., Tremblay, R.E.(2008). Predictive Validity and Early Predictors of Peer-Victimization Trajectories in Preschool. Arch Gen Psychiatry, 65(10), 1185-1192.

Barr-Anderson, D.J., Jayne A. Fulkerson, J.A., Smyth, M., Himes, J.H., Peter J. Hannan, P.J., Rock, B.H., and Story, M. (2011). Associations of American Indian Children's Screen-Time Behavior With Parental Television Behavior, Parental Perceptions of Children's Screen Time, and Media-Related Resources in the Home. Prev Chronic Dis, 8(5), A105.

Bendersky,M., Bennett,D., Lewis.(2006). Aggression at Age 5 as a Function of Prenatal Exposure to Cocaine, Gender, and Environmental Risk, Journal of Pediatric Psychology ,31 (1),71-84.

Blumer, H. (1933). Movies and Conduct. New York: Macmillan.

Bratic,V.(2008). Examining peace-oriented media in Areas of violent conflict. The International Communication Gazette, 70 (6), 487-503.

Broidy, L., Tremblay, R., Brame, B., Fergusson, D., Horword, J., Laird, R. (2003). Developmental trajectories of childhood disruptive behaviors and adolescent delinquency: A six-site, cross-national study. Developmental Psychology, 39, 222-245.

Bushman BJ, Huesmann LR. (2001). Effects of televised violence on aggression. In Handbook of Children and the Media, ed. D Singer, J Singer, pp. 223-54. Thousand Oaks, CA: Sage. 
Bushman, B. J., \& Huesmann, L. R. (2001). Effects of televised violence on aggression. In D. G. Singer \& J. L. Singer (Eds.), Handbook of children and the media (Ch. 11, pp. 223-254). Thousand Oaks, CA: Sage.

Chen, M. J., Miller, B.A., GRUBE, J.W., and Waiters, E.D. (2006). Music, Substance Use, and Aggression. Journal of Studies on Alcohol and Drugs. 67(3); 373-381.

Christakis,D.A.and Zimmerman,F.J.(2007).Violent Television Viewing During Preschool Is Associated With Antisocial Behavior During School Age. Pediatrics . 120 (5); 993 -999.

Comstock, G., \& Paik, H. (1991). Television and the American child. San Diego, CA: Academic Press.

Evans,C.A., Jordan,A.B.,and Horner,J.(2011).Only Two Hours? A Qualitative Study of the Challenges Parents Perceive in Restricting Child Television Time. Journal of Family Issues.32(9) 1223-1244.

Freedman, J. (2002).Media violence and its effect on aggression: Assessing the scientific evidence.Toronto: University of Toronto Press.

Funk,J.B., Baldacci,H.B., Pasold,T., Baumgardner,J.(2004). Violence exposure in real-life, video games, television, movies, and the internet: is there desensitization? Journal of Adolescence. 27, 23-39.

Gerbner ,G \& Gross ,L.(1976). The scary world of TV's heavy viewer. Psychol Today, 10(4):41-89.

Ghermez Cheshmeh, F., Moniri, Z., and Mirkhani, E. (2006). Role of mass media in children's delinquency. Available at: http://www.cidso.com/tahghigh/tv.htm

Grimes, T., Anderson, J., \& Bergen, L. (2008). Media violence and aggression: Science and ideology. Thousand Oaks, CA: Sage.

Hinton,W.J., Sheperis,C and Sims,P.(2003).Family-Based Approaches to Juvenile Delinquency: A Review of the Literature. The Family Journal, 11(2); 167-173.

Huesmann L. R, Moise-Titus, Podolski \& Eron, (2003) "Longitudinal relations between children's exposure to TV violence and their aggressive and violent behavior in young adulthood: 1977-1992," Developmental Psychology. 39(2); 201-21.

Johnson, J. G., Cohen, P., Smailes, E.M., Kasen, S. and Judith S. Brook, J.S. (2002). "Television viewing and aggressive behavior during adolescence and adulthood", Science, 295, 2468-2471.

Jones, K. E., Otten, J. J., Johnson, R. K., \& Harvey-Berino, J. R. (2010) Removing thebedroom television set: A possible method for decreasing television viewing time inoverweight and obese adults. Behavior Modification. 34, 290-298.

José Martínez, G.I., Prieto, M.D. \& Farfán, J.(2006).Childhood and Violence in Advertising : A Current Perspective, The International Communication Gazette , 68(3), 269-287.

Lahikainen, A. R., Korhonen, P., Kraav, I. \& Taimalu, M. (2004). Lasten turvattomuuden muutokset Suomessa ja Virossa. Teoksessa Alapuro, R. ja Arminen, Ilkka (toim): Vertailevan tutkimuksen ulottuvuuksia. WSOY, Helsinki.

Lahikainen,A.R., Taimalu, M.,Korhonen,P and Kraav,I.(2007). Self-Reported fears as indicators of Young Children's Well being in Societal change: a Cross - Cultural Perspective,Social Indicators Research, 80,51-78.

Mesri, K. (2011). Watching television in Iranian children. Jame Jam newspaper. 10th August 2011 available at: http://www.jamejamonline.ir/papertext.aspx?newsnum=100849464332

Mitrofan,O., Paul,M and Spencer,N.(2009). Is aggression in children with behavioural and emotional difficulties associated with television viewing and video game playing? A systematic review. Child: Care, Health and Development, 35(2), 5-15.

Mohammadi, N. (2007). Preliminary evaluation of psychometric indices of Buss - Perry 


\section{I Macrothink}

Aggression Questionnaire, Journal of Social Sciences and Humanities of Shiraz University. 25(4); 135-151.

Nunnally, JC. (1978). Psychometric theory. New York: McGraw-Hill.

Razavi, A., Jaafari, M. and Nowroozi, D. (2007). Association between Television program exposure and using information resources. Library and Information Science ,9(4),89-108.

Samani, S. (2008). Study of Reliability and Validity of the Buss and Perry's Aggression Questionnaire, Iranian Journal of Psychiatry and Clinical Psychology,13 (4), 359-365.

Savage.J (2008). The Role of Exposure to MediaViolence in the Etiology of Violent Behavior. American Behavioral Scientist,51(8),1123-1136.

Savage.J and Yancey,C.(2008). The Effects of Media Violence Exposure On Criminal Aggression : A Meta-Analysis, Criminal Justice And Behavior, 35 (6), 772-791.

Shanahan J, Morgan M.(1999).Television and its viewers: cultivation theory and research. Cambridge, UK: Cambridge University Press.

Sheikh, S. (1995). Entertainment time among type one urban adolescents. Presidential institution, Youth Council.

Taimalu, M. (2006). The Impact of Television on Children - it's Role as a Factor of Insecurity and Fears. In S.-L. Läänesaar (Ed.) Environment and Upbringing as Percept to Child's Future. Oü Vali Press trükikoda, Põltsamaa, 127-144.

Tremblay, R.E.(2008). Anger and Aggression. In: Haith. MM, Benson JB, eds. Encyclopedia of Infant and Early Childhood Development. Vol. 1-3. 2nd ed: Academic Press.

Vande berg, L.R., Wenner, L.A. \& Gronbeck, B.E. (2004). Media Literacy and Television Criticism: Enabling an Informed and Engaged Citizenry. American Behavioral Scientist, 48(2), 219-228.

Van der Geer, J., Hanraads, J. A. J., \& Lupton R. A. (2000). The art of writing a scientific article. Journal of Scientific Communications, 163, 51-59.

Vittrup, B. (2009). What US parents don't know about their children's television use, Discrepancies between parents' and children's reports. Journal of Children and Media, 3(1), 51-67.

World Health Organization (2000). Violence and Health. Proceedings of a WHO Global Symposium, 12-15 October 1999, Kobe, Japan.

Yoshimi,S.(2003).Television and Nationalism : Historical Change in the National Domestic TV Formation of Post-war Japan. European Journal of Cultural Study, 6 (4), 459-487. 